\title{
The Service Quality Experience of International Students: The Case of a Selected Higher Education Institution in South Africa
}

\author{
Jeevarathnam P Govender \\ Senior Lecturer, Department of Marketing and Retail Management, \\ Durban University of Technology, South Africa \\ E-mail: govendej@dut.ac.za
}

Dayaneethie Veerasamy

Lecturer, Department of Marketing and Retail Management, Durban University of Technology, South Africa

E-mail: veerasamyd@dut.ac.za

Dion T Noel

Lecturer, Department of Marketing and Retail Management, Durban University of Technology, South Africa

E-mail: dionn@dut.ac.za

\section{Doi:10.5901/mjss.2014.v5n8p465}

\begin{abstract}
The university, which forms the basis for this paper, has seen significant growth in the number of international student enrolments. It is against this background that international students' expectations and perceptions of service quality are assessed. A census was conducted among this group of students which comprised 215 respondents using the SERVQUAL instrument. The results indicate a high degree of internal consistency among the five dimensions of service quality in terms of both expectations and perceptions. It emerged that there were varying gaps in the twenty items that were measured, with the empathy dimension exhibiting the largest gap score. Recommendations are made on how the university can improve on service quality levels among its international students.
\end{abstract}

Keywords: Service quality, SERVQUAL, expectations of service quality, perceptions of service quality, higher education institution, international students

\section{Introduction}

Organisations have come to realise that providing quality service is key to differentiation from competitors as well as ensuring long term sustainability. Universities are no exception. The university has seen an increase in enrolment in the number of international students. This has prompted this paper which attempts to assess international students' expectations and perceptions of service quality at the university. The problem statement, aim and objectives are presented, followed by a literature review on service quality. The research methodology is explained. The findings of the empirical study are discussed, followed by recommendations for improving service quality. This paper may bear relevance, not only to other universities in South Africa, but also to higher education institutions in developing countries.

The university, situated in South Africa, has recently experienced a significant increase in enrolments by international students not only from other African states, but also from Asia, Australia, Europe and South America. According to Darlaston-Jones, Pike, Cohen, Young, Haunold and Drew (2003), the current climate in tertiary education places students as primary consumers who are becoming more conscious of their customer rights and of gaps between their expectations of service delivery and the reality of that service. Not only does this service gap present a quality assurance challenge for universities, it is also likely to contribute to withdrawal. If an organisation does not do market research on its service quality, it may fail in providing customer requirements (Zeithaml, Bitner and Gremler, 2006). The basis of this paper, therefore, is to determine the extent of the gap that exists between international students' expectations and perceptions of service quality at the university. 
The aim of this paper is to examine international students' expectations and perceptions of service quality. The research objectives are:

- To determine international students' expectations of customer service quality,

- To determine international students' perceptions of customer service quality, and

- To identify gaps between expectations and perceptions of customer service.

\section{Literature Review}

\subsection{Higher education in South Africa}

The past 15 years have seen the world gradually evolving from the ideological confines of the post-second World War structures to a more interdependent society and economy. However, the world is still divided into two parts, viz., the developed and developing worlds. The end of apartheid in South Africa has seen a new environment where competition for resources and strategic interests has increased. The greatest challenge for developing countries lies in the mobilisation of, and equipping their people with, knowledge to harness the benefits of a global economy. The information age has created for developing economies, an opportunity to level the playing field, in a world where knowledge is a prerequisite for any society to thrive (Michael, 2004).

Education has, for a long time, been recognised as a vehicle to achieve change, create new ideas and initiate new practices that move a country towards increasing prosperity (Wheatley, 2001). Higher education institutions are educating those individuals who will create and shape the future, as well as inform today's world. This makes the role of higher education more crucial in the current rapidly changing environment. Therefore, higher education institutions have a responsibility to several stakeholders (Freeman and Thomas, 2005).

The higher education industry in South Africa is a complex and competitive one The South African higher education landscape has witnessed accelerated transformation over the last decade. Higher education institutions in South Africa have experienced drastic changes in their structuring, operating, funding and student enrolments. Bunting and Cloete (2004) believe that the reduction in government subsidies has had a significant impact on the quality of teaching, learning and research and has led to overcrowding in many higher education institutions. This, in turn, has resulted in the general deterioration of physical facilities and a dwindling of resources such as text books, educational material and maintenance. The perceived quality has also impacted on the choice of institutions by prospective students. The challenges faced by higher education in South Africa is made more difficult through the integration of equity goals driven by national policy as a means of redressing inequalities of the past, in this instance, the higher education system (Badat, 2003).

The globalisation of higher education has also resulted in new entrants. Some of these strong, credible international providers have come into the South African market, bringing together a different level of integrity to the market to augment the offerings of existing providers. The government's plans to overhaul the higher education system in South Africa and the challenges brought about by globalisation have resulted in new challenges facing higher educational institutions. Such new challenges have included mergers and the transformation of Technikons into Universities of Technology. This move has not only led to a change of status for these institutions but has also brought about the merging of intrinsically different institutions. Access to higher education in South Africa, under the existing government policy, has seen a growth in the number of applications to higher education institutions (Bunting and Cloete, 2004).

According to Cooper and Subotzky (2001), South Africa has experienced a significant change relating to the increase in the number of black student enrolments in higher education, where the majority of new enrolments have been black since the mid 1990's. This calls for a reassessment of the needs of current students in higher education. The higher education sector has seen a significant reduction in government funding and an increase in student fees in countries such as the United Kingdom and Australia (Souter and Turner, 2002). This is as a result of macro environmental changes. Higher education institutions are facing increasing market and financial pressures in various countries. A consequence of this has been a more competitive higher education environment.

In light of the above, the effects of competition on institutions of higher education can be viewed as having farreaching implications. In the past, technikons and universities have been competing indirectly with each other. Today, the entire scenario has changed. These institutions now compete directly in the same market. The influence of technology and the demand for a technologically literate workforce has also led to a significant increase in private higher education institutions that also compete for both school leavers and post-graduate students. These private education providers are meeting a specific demand and are often more responsive to the market, compared to public institutions and offer qualifications in areas that the public sector does not (Kruss 2002). Private higher education continues to have a 
significant role to play, in South Africa and internationally, in meeting the skills demands of growing and changing economies. In many countries, private higher education provides some of the best research output, while, in others, private education took advantage of gaps in legislation, resulting in the provision of inferior education. In South Africa, there is still some scepticism and even stigma attached to private higher education.

The traditional student and their expectation and perception of service quality have changed and are still changing. Today's students, in higher education institutions, consist not only of young and mature students, but also more working class people, an increase in the number of women and more part-time students. They are more demanding in terms of service delivery (Wright and O'Neill, 2004). Service quality, as a component of overall quality, is at the forefront, being considered as one of the major components influencing student decision-making in higher education (McBurnie and Ziguras, 2007).

A study by Ben-Ami (2005) concluded that approximately one in three South African students across ten institutions surveyed, indicated that academic expectations have not been met, thus confirming a gap between expectations and perceptions.

\subsection{Service quality explained}

Customer service can be described as the totality of what the organisation does to add value to its products and services in the eyes of the customer. Quality is described as the measurement of how well the product or service of the organisation conforms to the customers' wants and expectations. Quality is the ability of the organisation to meet or exceed customer expectations (Brink and Berndt, 2010).

According to Lovelock and Wright (2007), after making a purchase, customers compare the service expected to what is actually received. Customers decide how satisfied they are with service delivery and outcomes, and they become judgemental regarding quality. Kurtz and Clow (2002) identify four inherent characteristics of services, not found in goods, viz. intangibility, perishability, inseparability and variability. These are briefly explained:

\subsubsection{Intangibility}

Intangibility relates to the lack of tangible characteristics which cannot be seen, touched, smelled, heard, or tasted prior to purchase (Bruhn and Georgi, 2006). Fitzsimmons and Fitzsimmons (2006) state that organizations always try to make their intangibility offer as tangible as possible, while many manufacturers try to create an image for their products instead of focusing on the tangible aspects of their products in advertising. Ganesan-Lim, Russell-Bennett and Dagger (2008) believe that customers find it difficult to determine the technical quality of the service and turn to the more easily evaluated tangible and physical aspects of the environment as substitute indicators of quality. A university will have to ensure that the physical appearance of the facilities and equipment is maintained at a high standard to ensure high levels of technical quality.

Armstrong and Kotler (2006) believe that because services cannot be seen, tasted, felt or heard, customers look for 'signals' of service quality to reduce uncertainty. Customers draw conclusions about quality from the place, price, equipment and communications that they can see. Therefore, the service provider must ensure the service is tangible in one or more ways and to send the right signals about quality. According to Brink and Berndt (2010), service quality involves all the activities that organizations and their employees conduct or perform to satisfy customers. Services are intangible, they are performances or actions rather than objects that can be felt or seen as with tangible goods (Zeithaml, Bitner and Gremler, 2006).

\subsubsection{Perishability}

Perishability of a service means the service cannot be inventoried or stored. The degree of perishability in the quality of service is affected by the degree of intangibility (Bruhn and Georgi, 2006). The perishability characteristic means that the service providers should be effective, i.e., have only one way that they should provide the right service the first time, every time. This provision also makes it impossible to have a quality check before the service can be sent to the customer.

\subsubsection{Inseparability}

Inseparability refers to the simultaneous production and consumption of services (Perez, Abad, Carrillo and Fernandez, 
2007). This kind of personal contact is referred to as "interactive consumption" and "interactive process" in the definition of services. It includes physical environment (e.g. an online search), behaviour of personnel, and the customer's mood and needs. According to Perez et al., (2007), inseparability of the service itself from the service provider highlights the role of people in the service transaction, and their influence on quality levels. Therefore, it is difficult for the service provider to hide mistakes or quality shortfalls of the service.

Goods can be produced and then sold at a later time; services cannot (Bruhn and Georgi, 2006). Armstrong and Kotler (2006) suggest that services cannot be separated from their providers, whether the providers are people or machines. If a service employee provides the service, then the employee becomes part of the service. Since the customer is also present as the service is produced, both the provider and the customer affect the service outcome.

\subsubsection{Variability}

Variability refers to the unwanted or random levels of service quality that customers receive when they patronize a service because they are produced by humans (Bruhn and Georgi, 2006). Fitzsimmons and Fitzsimmons (2006) consider the customer as being an integral part of the service process. He or she actively participates in the process of producing the service. The customer uses objective and subjective criteria to evaluate service quality.

Kotler and Keller (2006) suggest that no service will be precisely the same because services are produced by humans. There will always be variability because services depend on who provides them and when and where they are provided. According to Armstrong and Kotler (2006), the quality of services depends on who provides them as well as when, where, and how they are provided. Services involve people, and people are all different. There is a strong possibility that the same enquiry would be answered slightly differently by different people (or even by the same person at different times). It is important to minimise the differences in performance (through training, standard-setting and quality assurance).

\subsection{The dimensions of service quality}

Wilson, Zeithaml, Bitner and Gremler (2008) identify five dimensions of service quality. These can be demonstrated in relation to educational settings as follows:

\subsubsection{Tangibles}

The appearance of physical facilities such as lecture venues, libraries and eating facilities, equipment such as whiteboards and data projectors, the professional appearance of academic and support staff and communication materials central to providing a total educational experience (Zeithaml, Bitner and Gremler, 2006). Tangibles provide physical representations that customers will use to evaluate service quality. Dhurup, Singh and Surujlal (2006) view tangibles as the facilities, equipment and personal appearance of staff at the institution. Learning experience and orientation cannot entirely be evaluated by grades alone (Yeo, 2008). Most institutions use tangibles in conjunction with the other service quality dimensions to develop a service quality strategy for the organisation (Zeithaml, Bitner and Gremler, 2006).

\subsubsection{Reliability}

Yeo (2008) states that the discrepancy between the service promise and service delivery is often mainly due to inaccurate communication from advertisements and exhibitions. Many organisations tend to oversell their services, resulting in over-extended promises.

Blose and Tankersley (2004) believe that delivering a service and meeting commitments timeously, in keeping with the promised service timelines in a professional manner, will influence a customer's perception in a significant way. The employees at the institution should perform the desired service level correctly the first time. It also means the organisation keeps its promises within the specific time frame set out. If this delivery is done in an efficient manner, it will enhance the perceived quality of the customer (Brink and Berndt, 2010).

Lovelock and Wright (2007) are of the opinion that reliability is the most important factor in customers' assessment of service quality. Chowdhary and Prakash (2007) concur that, of all the dimensions of service quality, reliability is the most important. Reliability influences the assessment of other quality dimensions. Reliability improvements are at the forefront of service quality enhancement efforts because unreliable service means promises not being met on the 
attributes that customers care about the service received. If the main service is not performed reliably, customers may assume that the organisation is incompetent and may switch to another organisation.

\subsubsection{Responsiveness}

Responsiveness refers to the promptness and willingness of staff during the service encounter. This dimension focuses on attentiveness and timeous dealing with customers' requests, queries, complaints and problems. Dale (2007) regards responsiveness as the willingness to assist customers and to provide prompt service on a continuous basis. Responsiveness is present in the time period that customers have to wait for help, receive feedback to queries or attention to problems as well as the ability to develop personalised solutions for customers.

The staff at the institution must be willing and ready to serve and help customers. It is vital that the staff at the university be knowledgeable about the service they represent. Blose and Tankersley (2004) contend that, whether the interaction occurs face-to face or telephonically, the degree to which the service personnel exhibit the ability to handle such matters effectively, and whether they care about attending to the customer's request, will undoubtedly impact on perceptions of service quality. The learning process is expected to be academically rigorous and flexible in areas pertaining to course selection and assessment (Yeo 2008).

\subsubsection{Assurance}

Assurance relates to the ability of staff to provide a courteous and secure service. Arasli, Mehtap-Smadi and Katircioglu (2005) state that assurance constitutes employees' knowledge, courtesy and ability to inspire trust and confidence in the customer. This dimension is central to services since customers are confronted with a high level of risk or uncertainty about their ability to evaluate outcomes. Dhurup, Singh and Surujlal (2006) believe that assurance represents courtesy, credibility and competence on the part of employees. Bruhn and Georgi (2006) advocate that assurance is associated with the institution's ability to provide the service, mainly in terms of the knowledge, friendliness and trustworthiness on the part of employees. Zeithaml, Bitner and Gremler (2006) explain that trust and confidence can be enhanced by the individual who links the customer to the organisation. In a higher education institution, the key people that link the customer to the company would be the academic and frontline staff. The institution must provide assurance that employees have the ability to convey trust and confidence. To this end, an institution, with a strong brand, can communicate a signal of trust and confidence. The assessment of service quality depends to a large extent on how customers perceive the actual performance based on their expectation.

\subsubsection{Empathy}

Empathy refers to the provision of caring and individualised attention to the customer. The focal point of empathy highlights the message that customers are unique and special. Curry and Sinclair (2002) view empathy as providing caring, personalised attention to its customers. It is a challenge for higher education institutions to exceed customer expectations. The number of customers that the service provider has to deal with at one given time has a bearing on the level of individual attention given to each customer.

Brink and Berndt (2010) are of the opinion that higher education institutions and their employees must try to understand the customers' problems and strive to carry out duties with the customers' best interests in mind. Yeo (2008) believes that there is a greater need for managers to adopt a customer-orientation by showing a human dimension to their interaction with customers. Listening, understanding and communicating with the customer forms the foundation of empathy, e.g. students should be addressed by names and not by student numbers. This makes the student feel special.

\subsection{International students as customers}

Yeo (2008) offers two views of students as customers. The first view regards students as primary customers and associates them with being involved in the input and output of the learning process. The second view regards students' potential employers as primary customers, hence arguing that it is important to consider the economic reality of the situation where lesson contents should be tailored to employers' needs.

Jaraiedi and Ritz (1994) argue that students do not have a complete understanding of their learning needs. Education aims to prepare them for the future. It is with this view that potential employers are regarded as primary customers while students are regarded as secondary customers. Joseph and Joseph (1998), on the other hand, argue 
that students have to be regarded as the primary beneficiaries of education and, hence, should be treated as customers. This perspective stems from the notion that higher educational institutions are highly competitive in the marketplace with strategies being developed to satisfy student needs with a view to holding a sustainable market share.

\section{Research Methodology}

The study was cross sectional, quantitative and descriptive in nature. The questionnaire consisted of a 20 question modified version of the SERVQUAL instrument pioneered by Parasuraman, Zeithaml and Berry (1985). The use of SERVQUAL in the higher education landscape has been widely justified (Chua, 2004; O'Neill, 2003; Ruby, 1998; Zaftropoulos and Vrana, 2007). A five-point Likert scale (strongly disagree- strongly agree) was used.

For the purposes of this study, a census was conducted, considering the relatively small population of 215 enrolled international students at the university. The measuring instrument was pre-tested. Research assistants were used to administer the questionnaires. The results were analysed using the SPSS package.

\section{Results}

\subsection{Test for reliability}

The Cronbach coefficient alpha values in respect of the expectations and perceptions dimensions was 0.916 and 0.901 respectively. Govender and Pan (2011) propose that a reliability coefficient value of over 0.6 is acceptable. This suggests a high degree of internal consistency in this study.

\subsection{Analysis of expectations and perceptions by dimensions}

This section presents an analysis of the specific expectations versus perceptions for each of the five service quality dimensions. Each dimension is discussed in terms of its underlying items.

\subsubsection{Tangibles: expectations versus perceptions}

Figure 1 presents the items that constituted the tangibles dimension. The gap scores (in ascending order) for the four tangible items were materials associated with service $(0,49)$, having modern looking equipment $(0,65)$, physical facilities $(0,72)$, and communication and signage $(0,92)$. Of the four items, communication and signage was rated the highest expectation item, with physical facilities exhibiting the lowest perception score.

Figure 1: Tangibles: expectations versus perceptions

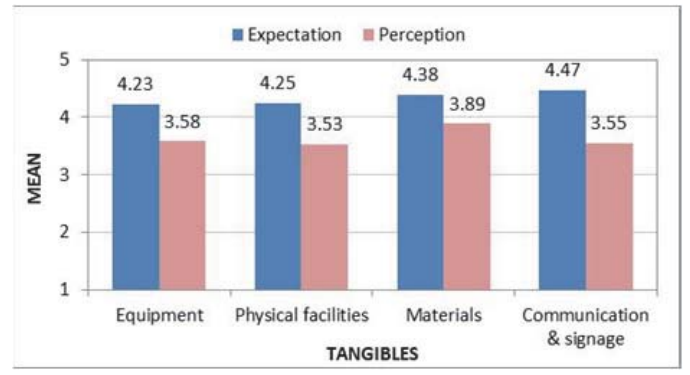

\subsubsection{Reliability: expectations versus perceptions}

Figure 2 reveals the expected and perceived scores for the reliability dimension. The fairness and reliability of assessments was ranked the highest in terms of expectations. It emerged that the perceptions of accurate record keeping had the lowest score. The gap scores for the four items (in ascending order) were: consistency in grading (0.59), accurate assessment of work by lecturers (0.62), fair and reliable assessment $(0.69)$ and the keeping of accurate records $(0.87)$. 
Figure 2: Reliability: expectations versus perceptions

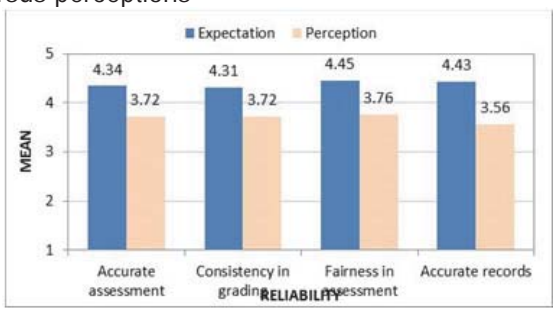

\subsubsection{Responsiveness: expectations versus perceptions}

The results, as presented in Figure 3, indicate that the highest expectation was for academic staff being concerned about the educational progress of their students, with the lowest perception applying to the item "giving useful advice upon the arrival of new international students".

The gap scores, when comparing expectations with perceptions for each item (in ascending order) were: academic staff being concerned about the educational progress of their students (0.63), administrative staff being courteous and willing to help (0.76) and giving useful advice when new students arrive (1.07).

Figure 3: Responsiveness: expectations versus perceptions

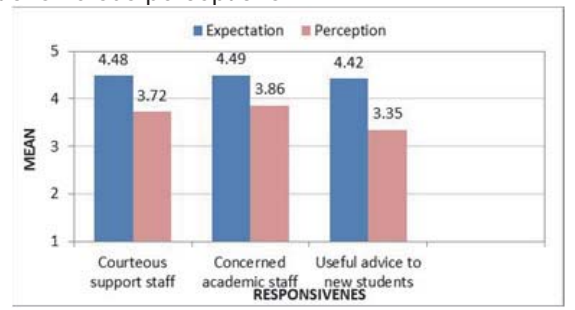

\subsubsection{Assurance: expectations versus perceptions}

Figure 4 presents the results of the findings on the items that constitute the assurance dimension. The highest expectation score applied to the item "getting value for money" and the item with the lowest perception score related to the living environment.

Figure 4: Assurance: expectations versus perceptions

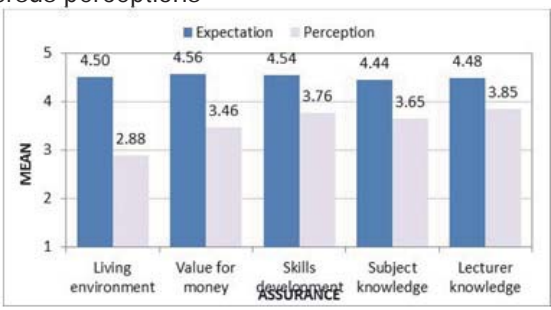

The gap scores for the assurance dimension (in ascending order) were: the extensive knowledge of lecturers in the field of learning (0.63), receiving knowledge to develop skills (0.78), international students gaining subject knowledge (0.79), getting value for money (1.1) and the provision for a good living environment (1.62), which had the largest gap score of all items.

\subsubsection{Empathy: expectations versus perceptions}

Of the four items pertaining to the empathy dimension, the highest expectation was that of foreign students being offered a range of support services whilst the lowest perception related to the item: easy access to staff who help with language 
and study skills.

The gap scores, when comparing expectations with perceptions for each item (in ascending order) were: sympathetic support staff $(0.99)$, access to staff to help international students (1.17), sympathetic academic staff (1.18) and adequacy of support services (1.20). The results are reflected in Figure 5.

Figure 5: Empathy: expectations versus perceptions

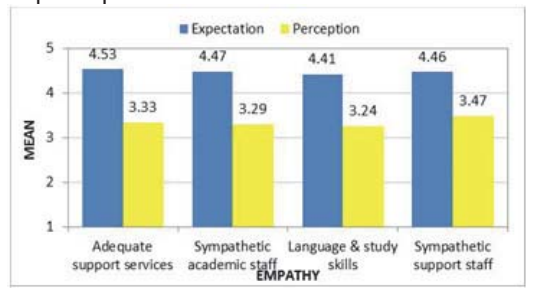

\subsection{Overall Gap Scores}

A profile of the expectations and perceptions of the service quality dimensions as well as the rankings are presented in Table 1. The SERVQUAL gap scores for each dimension are represented by their values in the P-E column.

Table 1: The SERVQUAL gap scores

\begin{tabular}{|l|c|c|c|c|}
\hline Dimension & Expectation(E) & Perception(P) & Score(P-E) & Rank \\
\hline Tangibles & 4.33 & 3.64 & 0.69 & 4 \\
\hline Reliability & 4.38 & 3.69 & 0.69 & 4 \\
\hline Responsiveness & 4.46 & 3.64 & 0.82 & 3 \\
\hline Assurance & 4.50 & 3.52 & 0.98 & 2 \\
\hline Empathy & 4.47 & 3.33 & 1.14 & 1 \\
\hline Mean & 4.43 & 3.56 & 0.87 & \\
\hline
\end{tabular}

The empathy dimension reflects the highest gap score (1.14) implying that it needs to be accorded the highest priority with regard to the improvement of service quality, followed by assurance and responsiveness, with tangibles and reliability having equal gap scores. The mean GAP score of 0.87 indicates that the perceptions of respondents do not meet with their expectations of overall service quality at the organisation.

\section{Recommendations and Conclusion}

Based on the findings, the following recommendations are made:

- Support staff must be trained in service quality-related programmes such as in the areas of customer service, product knowledge, communication and cultural diversity;

- Appropriate feedback mechanisms should be in place in order to assess whether deadlines were adhered to, promises were met, as well as dedication shown by staff to solve students' problems;

- The appropriate changes to technology and systems must be made so that they are supportive of the overall functioning of the institution, including being student-friendly and earning the trust and confidence of students;

- The communication and signage system must ensure that students are in a position to comprehend messages sent out to them;

- Accommodation facilities need to be improved so that international students are comfortable with using such facilities. To this end, attention should be paid to maintenance and upkeep of residences and the provision of support facilities; and

- Academic staff must understand the difficulties facing international students. There is a need to sensitise staff on issues pertaining to language, culture, communication and catering for the academic needs of international students.

This paper constituted an assessment of service quality by international students at a selected higher education institution in South Africa. The research problem was presented and the purpose of the study was stated. The research 
methodology was explained. The results indicate varying gap scores across the twenty items that were measured across the five service quality dimensions. The empathy dimension revealed the largest gap score. Recommendations for the enhancement of service quality are made.

\section{References}

Arasli, H.A., Mehtap-Smadi,S,. and Katircioglu, S.T. (2005). Customer service quality in the Greek Cypriot banking industry. Journal of Managing Service Quality, 15(1), 41-56.

Armstrong, G.,and Kotler, P. (2006). Marketing: An introduction (8 $8^{\text {th }}$ ed.). New Jersey: Prentice-Hall.

Badat, S. (2003).Transforming South African higher education 1990-2003: Goals, policy initiatives and critical challenges and issues in national policy and a regional response in South African Higher Education. [Online] Available: http:www.foundation-partnership.org/pubs/southafrica2004.pdf (September 10, 2011)

Bunting, I. and Cloete, N. (2004). Approaches to measuring performance in higher education: a South African case study. Draft Discussion Paper. Council on Higher Education Policy/ Change Dialogue. Cape Town. 9 March.

Ben-Ami, Z. (2005). Service quality in tertiary institutions. Unpublished M.Com. dissertation. Port Elizabeth: University of Port Elizabeth.

Blose, J.E., and Tankersley, W.B.(2004). Linking dimensions of service quality to original outcomes. Managing service quality, 14(1), 75-89.

Brink, A., and Berndt, A. (2010). Customer Relationship Management and Customer Service. Johannesburg: Juta and Company Ltd.

Bruhn, M., and Georgie, D. (2006). Service Marketing: Managing the service value chain. London: Prentice Hall, Pearson Education Limited.

Chowdhary, N.,and Prakash, M. (2007). Prioritizing service quality dimensions. Managing Service Quality, 17(5), 493-509.

Chua, C. (2004). Perception of Quality in Higher Education. Proceedings of the Australian Universities Quality Forum, AUQA Occasional Publication.

Cooper, D and Subotzky, G. (2001). The skewed revolution: trends in South African Higher education. Education Policy Unit, University of Western Cape.

Curry, A., and Sinclair, E. (2002). Assessing the quality of physiotherapy services using SERVQUAL. International Journal of Health Care Quality Assurance, 15(5), 197-205

Dale, B. G., Van der Wiele, T., and Van Iwaarden, J. (2007). Managing Quality. (5th ed.). Oxford: Blackwell Publishing.

Darlaston-Jones, D., Pike, L., Cohen, L., Young, A., Haunold, S., and Drew, N. (2003). "Are they being served? Student expectations of higher education." Issues in Educational Research, 13(1), 31-52.

Dhurup, M, Singh, P.C., and Surujlal, J. (2006). Customer Service Qualtiy at Commercial Health and Fitness Centres. South African Journal for Research in Sport, 28(2), 39-54.

Fitzsimmons, J.A., and Fitzsimmons, M.J. (2006). Service Management: operations, strategy, information technology. (5 $5^{\text {th }}$ ed.). Singapore: McGraw-Hill.

Freeman, I. and Thomas, M. (2005). Consumerism in education: a comparison between Canada and the United Kingdom. Intermational Journal of Management Education, 19 (2): 153-177.

Ganesan-Lim, C .,Russell-Bennett, R., and Dagger, T. (2008). The impact of service contact type and demographic characteristics on service quality perceptions. Journal of services Marketing, 22(7), 550-561.

Govender, J. P. and Pan, Q. (2011). Enhancement of Service Quality in the Intercity Bus Transport Industry. Alternation, 4, 181-202.

Jaraiedi, M., and Ritz, D. (1994). Total Quality Management Applied to Engineering Education. Quality Assurance in Education, 2, 32-40.

Joseph, M., and Joseph, B. (1998). Identifying Needs of Potential Students in Tertiary Education for Strategic Development. Quality Assurance in Education, 6(2), 90-96.

Kotler, P., and Keller, K. (2006). Marketing Management. (12 ${ }^{\text {th }}$ ed.). New Jersey: Prentice-Hall.

Kruss, G. (2002). Illuminating private higher education in SA. Business Day. 1st ed. April 10.

Kurtz, L.D., and Clow, K.E. (2002). Services Marketing. New York: John Wiley and Sons Incorporated.

Lovelock, C., and Wright, L. (2007). Principles of Service Marketing and Management. (5th ed.). New Jersey: Pearson Education Inc.

McBurnie, G. and Ziguras, C. (2007). Institutions, not students get the travel bug. Far Eastern Economic Review, 170(1): 58-61.

Michael, S.O. (2004). In search of universal principles of higher education management and applicability to Moldavian higher education system. International Journal of Educational Management, (18): 118-137.

O'Neill, M. (2003). The influence of Time on Students' Perceptions of Service Quality: The Need for Longitudinal Measures. Journal of Educational Administration, 14 (3), 310-325

Parasuraman, A., Zeithaml, V.A., and Berry, L. (1985). A conceptual model of service quality and the implications for future research. Journal of Marketing, 49, 41-50.

Perez, M.S., Abad, J.C., Carillo, G.M., and Fernandez, R.S. (2007). Effects of service quality dimensions on behavioural purchase intentions: A study in public-sector transport. Managing service quality, 17(2),134-151.

Ruby, C. (1998). Assessing Satisfaction with Selected Services using SERVQUAL, a Market-Driven Model of Service Quality. NASPA Journal, 35 (4), $7-14$.

Souter, G.N. and Turner, J.P. (2002). Students' preferences for university: a conjoint analysis. The International Journal of Educational Management, 16(1): 40-45

Wheatley, M.J. (2001). Restoring hope to the future through critical education for leaders. The Journal for Quality and Participation, 24(3): 46-49.

Wilson, A., Zeithaml, V.A., Bitner, M.J.,and Gremler, D.D. (2008). Services Marketing-Integrating Customer Focus Across the Firm. London: McGraw-Hill

Wright, C. and O' Neill, M. (2002). Service quality evaluation in the higher education sector: An empirical investigation of students' perceptions. Higher Education Research and Development, 21(1): 23-39.

Yeo, R.K. (2008). Brewing service quality in higher education. Quality assurance in education volume, 16(3), 266-286.

Zafiropoulos, C., and Vrana, V. (2007). Service Quality Assessment in a Greek Higher Education Institute. Journal of Business Economic and Management, 9,33-45.

Zeithaml, V.A., Bitner, M.J., and Gremler, D.D. (2006). Services Marketing: Intergrating Customer Focus across the Firm. (4 ${ }^{\text {th }}$ ed.). New York: McGraw-Hill. 